\title{
Exploring Factors Influencing Mobile Learning in Higher Education - A Systematic Review
}

\author{
https://doi.org/10.3991/ijim.v15i12.22503 \\ Yuvika Gupta \\ IMS Unison University, Dehradun, India \\ Farheen Mujeeb Khan $(\bowtie)$ \\ The ICFAI University, Dehradun, India \\ farheenk121@gmail.com \\ Sonal Agarwal \\ Datalink Institute of Business and Technology, Tema, Ghana
}

\begin{abstract}
To facilitate compelling learning experiences for the students, mobile learning (m-learning) has evolved as a powerful component of education - learning and teaching. Unlike electronic learning (e-learning), m-learning uses small and portable devices and laptops and desktops, primarily small and portable technological tools. M-learning helps impart knowledge focusing on the learner's need, accessibility, infrastructure, and interaction, irrespective of the place and time. With rapid advancements in Information and Communication Technologies (ICT) and mobile devices, myriad applications (Apps) and innovative m-learning and e-learning services are being developed and launched at an unprecedented pace. For students representing different demographics (age, education level, class, socioeconomic status, location) and enrolled in higher education, m-learning has quickly become the modern style and preferred format of learning and accessing knowledge to integrate different modes of learning. Motivated by this novel m-learning learning movement, this study synthesizes existing research on m-learning technologies and technological platforms that cater to synchronous and asynchronous learning/teaching modalities for students and teachers at higher education institutions.
\end{abstract}

Keywords-M-learning, TAM, UTAUT, Diffusion of innovation, Higher education

\section{Introduction}

Revolutionary change in technological progress has generated profound changes in individual living and working activities. Moreover, the relentless high-tech advancement and decrease in the price of mobile devices and services have made it a conventional usage device. The rapid and continuous need to access the information necessitates mobile devices used in the education sector, which has further transformed learning mode as mobile learning [1-3]. The extensive ownership of mobile gadgets 
has helped make it an educational tool, as it offers a focused learning environment to learners by negating the constraint of time and place [4-6]. Thus, mobile learning (mlearning) has widened the extent of educational opportunities in higher education (HE) [7]. M-learning empowers the learners with innovative learning opportunities, like personalized data, context-awareness, interactivity, communication, and collaboration. It also helps in linking both formal and informal education from different perspectives [8-12].

M-learning enables access to educational content globally, empowering interaction between individuals that cannot easily communicate face-to-face, which is believed to increase education effectiveness [13]. Furthermore, m-learning allows the reusing of educational materials and enables individually enhanced learning. On the contrary, researchers have claimed that students are less inclined to use e-learning systems [14] in their education even after the teachers' influence. The factors affecting mobile devices' usage among students are its reasonable price, assertiveness towards usage, determination, and focus on achievement and information controls [15],[16]. As stated in reference [17], mobile devices like palmtops, tablets, laptops, personal digital assistants, and mobile phones act as a learning tool with acceptable capability in lecture rooms and outside learning.

Thus, m-learning has proven to be an essential component of HE; its acceptance and adoption are of growing interest for researchers. There exist a massive variety of literature review studies concerning mobile-based learning. In conformity with the new inspired movement of learning, this review of prior research commences exploring the factors affecting students' acceptance of $\mathrm{m}$-learning and their behavioral intention to use it in an integrated way. Research has been conducted by going through existing literature and examining different approaches and models of m-learning.

\section{Methodology}

The well-known PRISMA statement by Moher et al. [18] was used for performing literature searches and exploring the most relevant articles (Fig. 1). The main criteria for inclusion of studies considered in the present research are:

- Only articles published in peer-reviewed journals are studied.

- Leading publications in the area of education technology were selected. Five-year h-index criteria of Google Scholar metrics were used to explore the top journal in education technology. From the following journals, three or more articles relating to the study were identified and considered for the present study: Education and Information Technologies, Telematics and Informatics, Computers \& Education, Computers in Human Behaviour. The journal's name and the number of articles included in the present study are mentioned in Table 1. Thesis dissertations and conference proceedings were not considered in the study due to not being subject to peer review. The last condition was that the studies selected must be published between January 2013 to September 2020, as this period represented the significant trends in the m-learning domain. 
- Students should have used mobile devices such as laptops, smartphones, and tablets for learning purposes in the included studies. Studies relating to specialized polling systems and electronic response systems were excluded from the study. Table 2 presents the inclusion and exclusion criteria incorporated in the current study.

Table 1. Educational technology journals considered.

\begin{tabular}{|c|l|c|}
\hline S.No. & \multicolumn{1}{|c|}{ Name of Journal } & Number of Articles \\
\hline 1. & Journal of Librarianship and Information Science & 2 \\
\hline 2. & International Journal of Business and Management & 1 \\
\hline 3. & Journal of Critical Reviews & 1 \\
\hline 4. & Education and Information Technologies & 4 \\
\hline 5. & Technology in Society & 2 \\
\hline 6. & International Journal of Networking and Virtual Organisations & 1 \\
\hline 7. & Educational Technology Research and Development & 2 \\
\hline 8. & Frontiers in Psychology & 1 \\
\hline 9. & Universal Access in the Information Society & 1 \\
\hline 10. & Computers in the Schools & 1 \\
\hline 11. & Australasian Journal of Educational Technology & 1 \\
\hline 12. & Telematics and Informatics & 3 \\
\hline 13. & International Journal of Interactive Mobile Technologies & 2 \\
\hline 14. & Journal of Systems and Information Technology & 1 \\
\hline 15. & Computers \& Education & 4 \\
\hline 16. & Interactive Technology and Smart Education & 1 \\
\hline 17. & Computers in Human Behaviour & 3 \\
\hline 18. & Computer Science \& Information Technology & 1 \\
\hline 19. & World Applied Sciences Journal & 1 \\
\hline 20. & International Review of Research in Open and Distance Learning & 1 \\
\hline 21. & SSRN Electronic Journal & 1 \\
\hline
\end{tabular}

Table 2. Inclusion and exclusion criteria.

\begin{tabular}{|l|l|}
\hline \multicolumn{1}{|c|}{ Inclusion criteria } & \multicolumn{1}{c|}{ Exclusion criteria } \\
\hline $\begin{array}{l}\text { Articles published in peer-reviewed journals are } \\
\text { considered }\end{array}$ & $\begin{array}{l}\text { Book chapters, conference papers, review studies, } \\
\text { dissertations are not considered }\end{array}$ \\
\hline $\begin{array}{l}\text { The study must be published between January } \\
2013 \text { to September 2020 }\end{array}$ & Clicker device studies are excluded \\
\hline $\begin{array}{l}\text { Students must use mobile devices such as tablets, } \\
\text { smartphones, and laptops. }\end{array}$ & Non-English articles \\
\hline
\end{tabular}



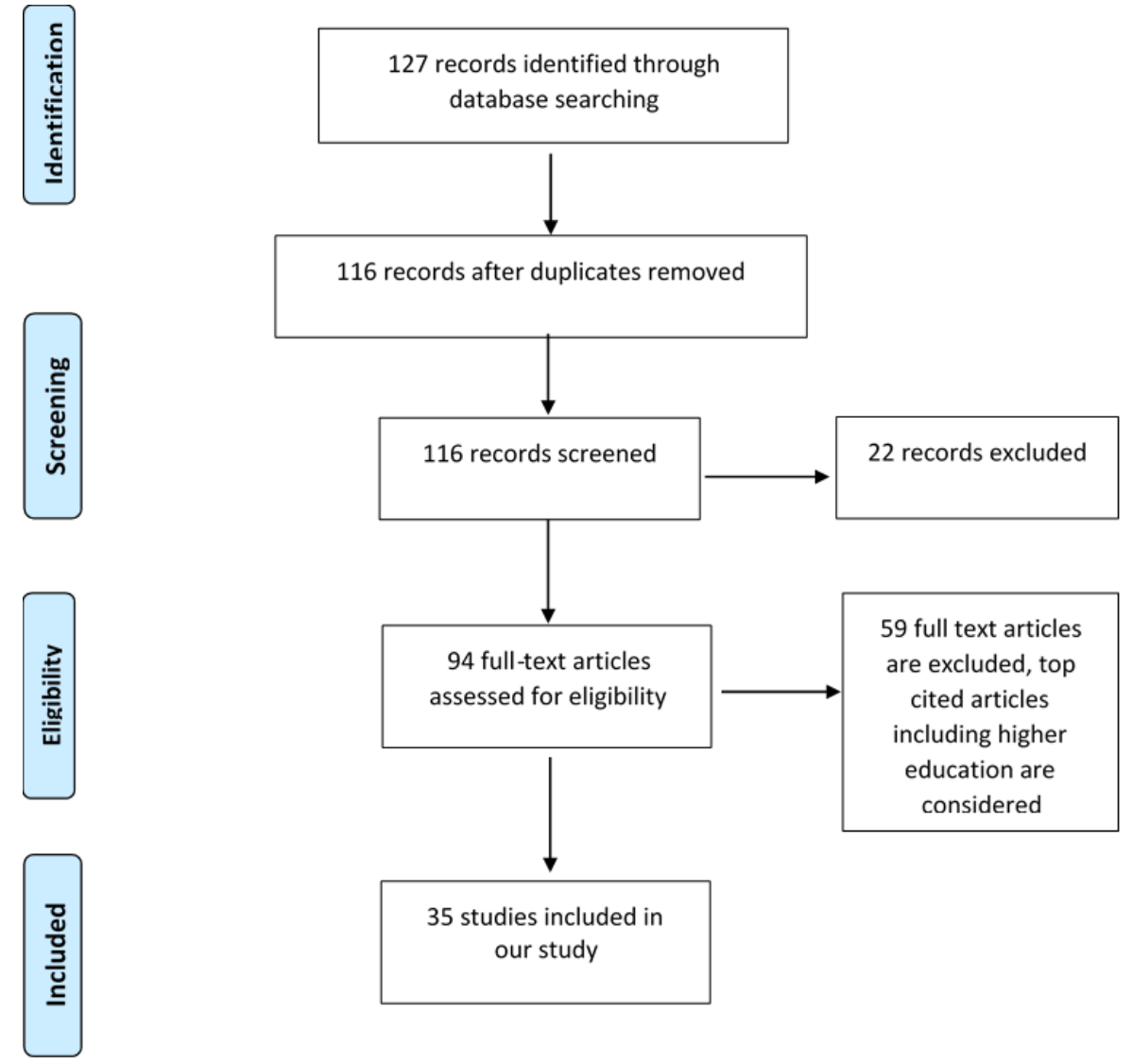

Fig. 1. PRISMA diagram (Moher et al., 2009)

\section{$3 \quad$ Literature Review}

The following study investigates the factors that influence HE's m-learning via a systematic literature review (SLR). The study comprises articles searched using the following query for titles, abstracts, and keywords section: ("Mobile learning" OR "m-learning") AND "Students" AND "higher education." The selected studies and research titles, methodologies, factors, and results are present in Table 3. 
Table 3. Review of studies table

\begin{tabular}{|c|c|c|c|c|}
\hline Studies & Research Title & Methodology & $\begin{array}{c}\text { Factors/ } \\
\text { Variables }\end{array}$ & Results \\
\hline $\begin{array}{l}\text { Zhang et } \\
\text { al. (2020) } \\
{[19]}\end{array}$ & $\begin{array}{l}\text { Medical stu- } \\
\text { dents' attitudes } \\
\text { and perceptions } \\
\text { towards the } \\
\text { effectiveness of } \\
\text { mobile learning: } \\
\text { A comparative } \\
\text { information- } \\
\text { need perspective }\end{array}$ & $\begin{array}{l}\text { Data were collected } \\
\text { from } 150 \text { respondents } \\
\text { through questionnaires. } \\
\text { The collected data was } \\
\text { examined through SPSS } \\
\text { with the help of descrip- } \\
\text { tive statistics. TAM } \\
\text { model was analyzed. }\end{array}$ & \begin{tabular}{|l} 
Perceived use- \\
fulness (PU), \\
perceived ease of \\
use (PEOU), \\
attitude (ATT), \\
behavioral \\
intention (BI)
\end{tabular} & $\begin{array}{l}\text { Medical students use their mobile } \\
\text { phones for networking through } \\
\text { social media, relaxation, and enter- } \\
\text { tainment activities easily accessible. } \\
\text { Societal standards and medical } \\
\text { discipline disparities are strongly } \\
\text { linked with PU, PEOU, ATT, and } \\
\text { BI. } \\
\text { The easy access to the system was } \\
\text { the main driving force behind the } \\
\text { positive influence of PEOU. } \\
\text { Social norms represent most promi- } \\
\text { nent aspect that positively correlates } \\
\text { to PU, ATT, and BI. }\end{array}$ \\
\hline $\begin{array}{l}\text { Alotaibi } \\
\text { et al. } \\
(2020) \\
{[20]}\end{array}$ & \begin{tabular}{|l|} 
Factors influ- \\
encing ac- \\
ceptance to use \\
m-learning in \\
learning the \\
Arabic language \\
for non-native \\
speakers in \\
Saudi universi- \\
ties
\end{tabular} & $\begin{array}{l}\text { Data was collected from } \\
460 \text { respondents through } \\
\text { paper-based question- } \\
\text { naires. } \\
\text { SmartPLS } 3.0 \text { was used } \\
\text { for analysis. The ex- } \\
\text { tended UTAUT model } \\
\text { was analyzed. }\end{array}$ & $\begin{array}{l}\text { FC, EE, per- } \\
\text { ceived enjoy- } \\
\text { ment, perceived } \\
\text { interactivity, } \\
\text { expected per- } \\
\text { formance, con- } \\
\text { tent quality, BI }\end{array}$ & $\begin{array}{l}\text { The extended factors, i.e., language } \\
\text { interactivity, system enjoyment, and } \\
\text { content quality, are significantly } \\
\text { related to BI. FC and EE had a } \\
\text { significant impact on BI to use m- } \\
\text { learning in education. }\end{array}$ \\
\hline $\begin{array}{l}\text { Hu et al. } \\
(2020) \\
{[21]}\end{array}$ & \begin{tabular}{|l|} 
Exploring \\
factors affecting \\
academics' \\
adoption of \\
emerging mo- \\
bile technolo- \\
gies-an extended \\
the UTAUT \\
perspective
\end{tabular} & \begin{tabular}{|l|} 
Data was collected from \\
638 participants using a \\
questionnaire of a \\
seven-point Likert scale. \\
SPSS 24.0 and \\
SmartPLS-SEM 3.0 \\
were used for analysis \\
Independent sample t- \\
test and one-way ANO- \\
VAs were conducted to \\
compare academics' \\
perceptions of mobile \\
technologies' adoption \\
factors.
\end{tabular} & $\begin{array}{l}\text { Performance } \\
\text { expectancy (PE), } \\
\text { EE, social influ- } \\
\text { ence (SI), FC, } \\
\text { hedonic motiva- } \\
\text { tion (HM), Price } \\
\text { value (PV), habit } \\
(\mathrm{HB}), \mathrm{BI}\end{array}$ & $\begin{array}{l}\text { PE, FC, HM, HB, and BI signifi- } \\
\text { cantly impact user behavior towards } \\
\text { mobile technologies. } \\
\text { HB has been proved to be the most } \\
\text { significant predictor of BI. } \\
\text { EE and PV were not significant } \\
\text { predictors of BI. } \\
\text { The moderators' age, gender, and } \\
\text { experience have a negative impact } \\
\text { on the relationship between EE and } \\
\text { BI. }\end{array}$ \\
\hline $\begin{array}{l}\text { Hoi } \\
(2020) \\
{[22]}\end{array}$ & $\begin{array}{l}\text { Understanding } \\
\text { higher education } \\
\text { learners' ac- } \\
\text { ceptance and } \\
\text { use of mobile } \\
\text { devices for } \\
\text { language learn- } \\
\text { ing: A Rasch- } \\
\text { based path } \\
\text { modeling ap- } \\
\text { proach }\end{array}$ & $\begin{array}{l}\text { Data was collected } \\
\text { through an online } \\
\text { questionnaire from } 293 \\
\text { respondents. } \\
\text { Structural Equation } \\
\text { Modelling (SEM), } \\
\text { AMOS, and Rasch- } \\
\text { based path model were } \\
\text { for analysis. The modi- } \\
\text { fied version of the } \\
\text { UTAUT model was } \\
\text { applied. }\end{array}$ & $\begin{array}{l}\text { PE, EE, SI, FC, } \\
\text { ATT, BI }\end{array}$ & $\begin{array}{l}\text { ATT toward Mobile assistant lan- } \\
\text { guage learning (MALL) was found } \\
\text { to be the most potent predictor of } \\
\text { learners' BI. } \\
\text { PE was a significant predictor of } \\
\text { students' attitudes toward the use of } \\
\text { MALL. } \\
\text { EE has no direct effect on BI. } \\
\text { FC has no direct effect on user } \\
\text { behavior. } \\
\text { Limited access to high-speed wire- } \\
\text { less networks, insufficient budget, } \\
\text { and a technical assistant's absence } \\
\text { prevent the respondents from using } \\
\text { mobile devices to learn a foreign }\end{array}$ \\
\hline
\end{tabular}




\begin{tabular}{|c|c|c|c|c|}
\hline & & & & $\begin{array}{l}\text { language on a continuous and } \\
\text { regular basis. }\end{array}$ \\
\hline $\begin{array}{l}\text { Nawaz et } \\
\text { al. }(2020) \\
{[23]}\end{array}$ & $\begin{array}{l}\text { Acceptance of } \\
\text { mobile learning } \\
\text { by higher educa- } \\
\text { tional institu- } \\
\text { tions in Sri } \\
\text { Lanka: An } \\
\text { UTAUT2 } \\
\text { approach }\end{array}$ & $\begin{array}{l}\text { Data was collected from } \\
453 \text { respondents through } \\
\text { printed hard copies and } \\
\text { online forms. } \\
\text { SPSS and AMOS } \\
\text { analyzed the data. } \\
\text { UTAUT2 model was } \\
\text { analyzed. }\end{array}$ & $\begin{array}{l}\text { PE, EE, SI, FC, } \\
\mathrm{HB}, \mathrm{HM}\end{array}$ & $\begin{array}{l}\text { PE, EE, HB, FC, and HM influ- } \\
\text { enced Sri Lankan students' BI to use } \\
\text { m-learning }\end{array}$ \\
\hline $\begin{array}{l}\text { Ameri et } \\
\text { al. }(2020) \\
{[24]}\end{array}$ & $\begin{array}{l}\text { Acceptance of a } \\
\text { mobile-based } \\
\text { educational } \\
\text { application } \\
\text { (LabSafety) by } \\
\text { pharmacy } \\
\text { students: An } \\
\text { application of } \\
\text { the UTAUT2 } \\
\text { model }\end{array}$ & $\begin{array}{l}\text { Data was collected from } \\
241 \text { pharmacy students } \\
\text { through a questionnaire } \\
\text { designed considering } \\
\text { the UTAUT2 model. } \\
\text { PLS-SEM was used to } \\
\text { analyze the data. }\end{array}$ & $\begin{array}{l}\text { PE, EE, SI, FC, } \\
\text { HB, BI, use } \\
\text { behavior (UB) }\end{array}$ & $\begin{array}{l}\text { PE, SI, and HB have a significant } \\
\text { effect on BI of pharma students. } \\
\text { BI has a significant impact on UB. } \\
\text { The use of information technology } \\
\text { in education and learning affected } \\
\text { the students' BI. }\end{array}$ \\
\hline $\begin{array}{l}\text { Ni- } \\
\text { kolopou- } \\
\text { lou et al. } \\
(2020) \\
{[25]}\end{array}$ & $\begin{array}{l}\text { Acceptance of } \\
\text { mobile phone by } \\
\text { university } \\
\text { students for } \\
\text { their studies: an } \\
\text { investigation } \\
\text { applying } \\
\text { UTAUT2 model }\end{array}$ & $\begin{array}{l}\text { Data was collected from } \\
540 \text { university students } \\
\text { through Google Forms. } \\
\text { Variance-Based Struc- } \\
\text { tural Equation Modeling } \\
\text { (VB-SEM) and PLS- } \\
\text { SEM were applied for } \\
\text { analysis. }\end{array}$ & $\begin{array}{l}\text { PE, EE, SI, FC, } \\
\text { HM, PV, HB, } \\
\text { BI, UB }\end{array}$ & $\begin{array}{l}\text { EE and PV have no significant } \\
\text { impact on BI. } \\
\text { HB was the most significant driver } \\
\text { of BI to use a mobile phone by the } \\
\text { students. } \\
\text { PE has a significant impact on the } \\
\text { BI of students towards the use of } \\
\text { the mobile phone. Students perceive } \\
\text { that using mobile phones will help } \\
\text { them in improving their academic } \\
\text { performance. }\end{array}$ \\
\hline $\begin{array}{l}\text { Chatter- } \\
\text { jee et al. } \\
(2020) \\
{[26]}\end{array}$ & $\begin{array}{l}\text { Adoption of } \\
\text { mobile applica- } \\
\text { tions for teach- } \\
\text { ing-learning } \\
\text { process in rural } \\
\text { girls' schools in } \\
\text { India: an empir- } \\
\text { ical study }\end{array}$ & $\begin{array}{l}\text { The data was collected } \\
\text { from } 271 \text { respondents, } \\
\text { including both students } \\
\text { and teachers, through } \\
\text { convenience sampling. } \\
\text { PLS-SEM was used for } \\
\text { the analysis of data. }\end{array}$ & $\begin{array}{l}\text { PU, PEOU, } \\
\text { Perceived Risk, } \\
\text { EE, PV, BI, } \\
\text { Adoption of } \\
\text { mobile applica- } \\
\text { tion (AMA) }\end{array}$ & $\begin{array}{l}\text { PEOU, EE, and PU have a signifi- } \\
\text { cant positive impact on the BI. } \\
\text { Perceived Risk has a negative but } \\
\text { significant impact on the BI. } \\
\text { PV has no direct impact on the BI. }\end{array}$ \\
\hline $\begin{array}{l}\text { Al- } \\
\text { Azawei \& } \\
\text { Alowayr } \\
(2020) \\
{[27]}\end{array}$ & $\begin{array}{l}\text { Predicting the } \\
\text { intention to use } \\
\text { and hedonic } \\
\text { motivation for } \\
\text { mobile learning: } \\
\text { A comparative } \\
\text { study in two } \\
\text { Middle Eastern } \\
\text { countries }\end{array}$ & $\begin{array}{l}\text { Data was collected from } \\
469 \text { students through a } \\
\text { questionnaire designed } \\
\text { on a five-point Likert } \\
\text { scale. Convenience } \\
\text { sampling was used for } \\
\text { data collection. } \\
\text { SPSS was used for } \\
\text { descriptive and inferen- } \\
\text { tial statistics. } \\
\text { SmartPLS was used for } \\
\text { analysis, Pearson corre- } \\
\text { lation, one-way } \\
\text { ANOVA test was } \\
\text { applied. }\end{array}$ & $\begin{array}{l}\text { BI, EE, HM, PE, } \\
\text { PV, SI, Trust }\end{array}$ & $\begin{array}{l}\text { The trust factor was incorporated in } \\
\text { the UTAUT2 model. } \\
\text { PE was the most significant predic- } \\
\text { tor influencing the BI towards the } \\
\text { use of m-learning. } \\
\text { PV was the most significant predic- } \\
\text { tor influencing the BI. } \\
\text { Trust and HM had a significant } \\
\text { impact on BI. }\end{array}$ \\
\hline $\begin{array}{l}\text { Al- } \\
\text { Na- } \\
\text { wayseh, }\end{array}$ & $\begin{array}{l}\text { Mobile learning } \\
\text { adoption in } \\
\text { Jordan: Tech- }\end{array}$ & $\begin{array}{l}\text { Data was collected from } \\
300 \text { respondents through } \\
\text { questionnaires designed }\end{array}$ & $\begin{array}{l}\text { BI, EE, PE, FC, } \\
\text { SI }\end{array}$ & $\begin{array}{l}\text { PE, EE, and SI have a significant } \\
\text { positive impact on BI to adopt m- } \\
\text { learning. }\end{array}$ \\
\hline
\end{tabular}




\begin{tabular}{|c|c|c|c|c|}
\hline $\begin{array}{l}\text { et al. } \\
(2020) \\
{[28]}\end{array}$ & $\begin{array}{l}\text { nology influenc- } \\
\text { ing factors }\end{array}$ & $\begin{array}{l}\text { on a five-point Likert } \\
\text { scale. UTAUT model } \\
\text { was analyzed. }\end{array}$ & & $\begin{array}{l}\text { FC did not have a significant impact } \\
\text { on BI. }\end{array}$ \\
\hline $\begin{array}{l}\text { Hwang et } \\
\text { al. (2020) } \\
{[29]}\end{array}$ & \begin{tabular}{|l|} 
A long-term \\
experiment to \\
investigate the \\
relationships \\
between high \\
school students' \\
perceptions of \\
mobile learning \\
and peer interac- \\
tion and higher- \\
order thinking \\
tendencies \\
\end{tabular} & $\begin{array}{l}\text { Data was collected from } \\
658 \text { respondents with } \\
\text { the help of a question- } \\
\text { naire designed on a 5- } \\
\text { point Likert scale. } \\
\text { EFA, CFA, and SEM } \\
\text { are used for the data } \\
\text { analysis. }\end{array}$ & $\begin{array}{l}\text { Ease of use } \\
\text { (EU); continuity } \\
(\mathrm{CN}) \text {; Adaptive } \\
\text { content (AC); } \\
\text { Collaboration } \\
\text { (CL) Communi- } \\
\text { cation (CO) } \\
\text { Problem-solving } \\
\text { (PS) Critical } \\
\text { thinking (CT) } \\
\text { Creativity (CA) }\end{array}$ & $\begin{array}{l}\text { CA and CT had a strong relation- } \\
\text { ship with CO and CL in the aspect } \\
\text { of interaction with learners. } \\
\text { CL and AC are highly interconnect- } \\
\text { ed; to assist students in collabora- } \\
\text { tive m-learning, multiple relevant } \\
\text { learning material is essential. } \\
\text { The ease-of-use dimension of } \\
\text { interaction with technologies was } \\
\text { not related to any dimension of } \\
\text { interaction with learners. }\end{array}$ \\
\hline $\begin{array}{l}\text { Al-Emran } \\
\text { et al. } \\
(2020) \\
{[30]}\end{array}$ & \begin{tabular}{|l|} 
Towards a \\
conceptual \\
model for \\
examining the \\
impact of \\
knowledge \\
management \\
factors on \\
mobile learning \\
acceptance
\end{tabular} & $\begin{array}{l}\text { Data was collected from } \\
416 \text { students using the } \\
\text { convenience sampling } \\
\text { technique. } \\
\text { PLS-SEM was used for } \\
\text { the analysis of data. } \\
\text { TAM model was ana- } \\
\text { lyzed. }\end{array}$ & $\begin{array}{l}\text { Actual Use, BI, } \\
\text { Knowledge } \\
\text { Acquisition, } \\
\text { Knowledge } \\
\text { Application, } \\
\text { Knowledge } \\
\text { Protection, } \\
\text { Knowledge } \\
\text { Sharing, PEOU, } \\
\text { PU }\end{array}$ & $\begin{array}{l}\text { Knowledge acquisition, application, } \\
\text { and protection positively impact PU } \\
\text { and PEOU, affecting the behavioral } \\
\text { intention to use and actual use. } \\
\text { PEOU was the most significant } \\
\text { driver of BI. }\end{array}$ \\
\hline $\begin{array}{l}\text { Chao } \\
(2019) \\
{[31]}\end{array}$ & $\begin{array}{l}\text { Factors deter- } \\
\text { mining the } \\
\text { behavioral } \\
\text { intention to use } \\
\text { mobile learning: } \\
\text { An application } \\
\text { and extension of } \\
\text { the UTAUT } \\
\text { model } \\
\end{array}$ & $\begin{array}{l}\text { Data was collected } \\
\text { through a questionnaire } \\
\text { from 2,000 students } \\
\text { using a 5-point Likert } \\
\text { scale. } \\
\text { PLS-SEM was used to } \\
\text { validate structured data. } \\
\text { UTAUT model was } \\
\text { analyzed. }\end{array}$ & $\begin{array}{l}\text { Perceived En- } \\
\text { joyment, EE, PE, } \\
\text { Satisfaction; } \\
\text { Trust; Mobile } \\
\text { Self-efficacy; } \\
\text { Perceived Risk } \\
\text { (PR); BI }\end{array}$ & $\begin{array}{l}\text { The moderating effect of PR on the } \\
\text { EE and BI relationship is insignifi- } \\
\text { cant. } \\
\text { PR negatively moderated the rela- } \\
\text { tionship between PE and BI. }\end{array}$ \\
\hline $\begin{array}{l} \\
\\
\text { Chavoshi } \\
\text { \& Hamidi } \\
(2019) \\
{[32]}\end{array}$ & $\begin{array}{l}\text { Social, individ- } \\
\text { ual, technologi- } \\
\text { cal and peda- } \\
\text { gogical factors } \\
\text { influencing } \\
\text { mobile learning } \\
\text { acceptance in } \\
\text { higher educa- } \\
\text { tion: A case } \\
\text { from Iran }\end{array}$ & $\begin{array}{l}\text { The data was collected } \\
\text { from } 257 \text { respondents } \\
\text { using snowball sam- } \\
\text { pling. } \\
\text { Partial Least Squares } \\
\text { Artificial Neural Net- } \\
\text { works (PLS-ANN) were } \\
\text { used to analyze the } \\
\text { collected data. } \\
\text { TAM and UTAUT } \\
\text { combination models are } \\
\text { used. }\end{array}$ & $\begin{array}{l}\text { User Interface, } \\
\text { Mobile Device } \\
\text { Limitations, } \\
\text { Government } \\
\text { Support, Social } \\
\text { Influence, Per- } \\
\text { sonal Innova- } \\
\text { tiveness (PI), } \\
\text { Self-efficacy, } \\
\text { Trust, PU, } \\
\text { PEOU }\end{array}$ & $\begin{array}{l}\text { Individual, pedagogical, social, and } \\
\text { technological factors significantly } \\
\text { affect selecting mobile devices for } \\
\text { m-learning. } \\
\text { Perceived usefulness was the most } \\
\text { significant driver for acceptance of } \\
\text { m-learning in Iran. } \\
\text { PI has proved to be insignificant in } \\
\text { impacting the acceptance of m- } \\
\text { learning in HE. } \\
\text { Pedagogy of teaching had a consid- } \\
\text { erable impact on the PU while } \\
\text { technological and individual factors } \\
\text { are significant on PEOU. } \\
\text { Social influence has a positive } \\
\text { effect on PU and PEOU. }\end{array}$ \\
\hline $\begin{array}{l}\text { Arain et } \\
\text { al. (2019) } \\
{[33]}\end{array}$ & \begin{tabular}{|l|} 
Extending \\
UTAUT2 \\
toward ac- \\
ceptance of \\
mobile learning \\
in the context of \\
higher education
\end{tabular} & $\begin{array}{l}\text { The data were collected } \\
\text { by stratified random } \\
\text { sampling method using } \\
\text { a 7-point Likert scale. } \\
\text { SEM was used to ana- } \\
\text { lyze the collected data. } \\
\text { The extended UTAUT2 } \\
\text { model was analyzed. }\end{array}$ & $\begin{array}{l}\text { PE, EE, FC, SI, } \\
\text { HM, HB, BI, } \\
\text { Ubiquity, Infor- } \\
\text { mation quality } \\
\text { (IQ), System } \\
\text { quality (SQ), } \\
\text { Appearance } \\
\text { quality, }\end{array}$ & $\begin{array}{l}\mathrm{HB}, \mathrm{PE} \text {, and HM have a significant } \\
\text { impact on the BI of students. } \\
\text { The new constructs ubiquity and } \\
\text { satisfaction were significant drivers } \\
\text { which impact the BI of students. } \\
\text { EE, FC, and SI were not statistically } \\
\text { significant predictors of the stu- } \\
\text { dents' BI toward m-learning ac- }\end{array}$ \\
\hline
\end{tabular}




\begin{tabular}{|c|c|c|c|c|}
\hline & & & Satisfaction & $\begin{array}{l}\text { ceptance. } \\
\text { Ubiquity, IQ, SQ, appearance } \\
\text { quality, and satisfaction as a media- } \\
\text { tor significantly impact m-learning } \\
\text { acceptance. }\end{array}$ \\
\hline $\begin{array}{l}\text { Fagan } \\
(2019) \\
{[34]}\end{array}$ & $\begin{array}{l}\text { Factors Influ- } \\
\text { encing Student } \\
\text { Acceptance of } \\
\text { Mobile Learning } \\
\text { in Higher Edu- } \\
\text { cation }\end{array}$ & $\begin{array}{l}\text { The data was collected } \\
\text { from } 171 \text { participants } \\
\text { through a survey shared } \\
\text { by email link online. } \\
\text { PLS-SEM was used to } \\
\text { analyze the data, and the } \\
\text { UTAUT model was } \\
\text { analyzed. }\end{array}$ & $\begin{array}{l}\text { PE, EE, SI, HM, } \\
\text { and BI }\end{array}$ & $\begin{array}{l}\text { HM and SI were not significant on } \\
\text { BI. } \\
\text { PE fully mediates the effect of HM } \\
\text { and SI toward students' BI. Stu- } \\
\text { dents in the study perceived iPads } \\
\text { as valuable and enjoyable tools for } \\
\text { accomplishing educational tasks } \\
\text { and improving learning outcomes. }\end{array}$ \\
\hline $\begin{array}{l}\text { Moorthy } \\
\text { et al. } \\
(2019) \\
{[35]}\end{array}$ & $\begin{array}{l}\text { Habit and hedonic } \\
\text { motivation are the } \\
\text { strongest influences } \\
\text { in mobile learning } \\
\text { behaviors among } \\
\text { higher education } \\
\text { students in Malay- } \\
\text { sia. }\end{array}$ & $\begin{array}{l}\text { Data was collected from } \\
358 \text { respondents through } \\
\text { questionnaires shared on } \\
\text { the internet (Google } \\
\text { Form) } \\
\text { PLS-SEM was used to } \\
\text { analyze the data. }\end{array}$ & $\begin{array}{l}\text { PE, EE, FC, SI, } \\
\mathrm{HM}, \mathrm{HB}, \mathrm{PV}, \mathrm{BI}\end{array}$ & $\begin{array}{l}\text { Amongst all the factors, HB act as } \\
\text { the most significant predictor influ- } \\
\text { encing students' intention to adopt } \\
\text { m-learning. }\end{array}$ \\
\hline $\begin{array}{l}\text { Hamidi \& } \\
\text { Ja- } \\
\text { hansha- } \\
\text { heefard } \\
(2019) \\
{[36]}\end{array}$ & \begin{tabular}{|l|} 
Essential factors \\
for the applica- \\
tion of educa- \\
tion information \\
system using \\
mobile learning: \\
A case study of \\
students of the \\
university of \\
technology \\
\end{tabular} & \begin{tabular}{|l} 
Data was collected from \\
300 students selected \\
randomly. \\
SPSS and AMOS were \\
used for the analysis of \\
collected data.
\end{tabular} & $\begin{array}{l}\text { Ease of use, } \\
\text { Culture of using } \\
\text { m-learning, BI, } \\
\text { Student trust, } \\
\text { Usefulness, M- } \\
\text { learning }\end{array}$ & $\begin{array}{l}\text { The results of the study reflect } \mathrm{m} \text { - } \\
\text { learning has a significant impact on } \\
\text { student satisfaction. } \\
\text { The study reported that the educa- } \\
\text { tion level of students impacts the } \\
\text { expectations and satisfaction of } \\
\text { students towards m-learning. }\end{array}$ \\
\hline $\begin{array}{l}\text { Hamidi \& } \\
\text { Chavoshi } \\
(2018) \\
{[37]}\end{array}$ & \begin{tabular}{|l|} 
Analysis of the \\
essential factors \\
for the adoption \\
of mobile learn- \\
ing in higher \\
education: A \\
case study of \\
students of the \\
University of \\
Technology \\
\end{tabular} & $\begin{array}{l}\text { Data was collected from } \\
300 \text { students with the } \\
\text { help of a questionnaire } \\
\text { designed on a 5-point } \\
\text { Likert scale. } \\
\text { SEM, CFA, and AMOS } \\
\text { were used to test the } \\
\text { adoption of m-learning }\end{array}$ & $\begin{array}{l}\text { Trust, Characters } \\
\text { and personal } \\
\text { qualities, BI, } \\
\text { Context, Ease of } \\
\text { use, Usefulness, } \\
\text { Culture of using }\end{array}$ & $\begin{array}{l}\text { Trust has a direct and positive } \\
\text { relationship with the BI. } \\
\text { Personal qualities do not have a } \\
\text { significant impact on BI. }\end{array}$ \\
\hline $\begin{array}{l}\text { Kim \& } \\
\text { Rha, } \\
(2018)[1]\end{array}$ & \begin{tabular}{|l|} 
Predicting the \\
Drivers of the \\
Intention to Use \\
Mobile Learning \\
in South Korea
\end{tabular} & $\begin{array}{l}\text { Data was collected } \\
\text { through a questionnaire } \\
\text { from } 580 \text { people, using } \\
\text { 5- point Likert scale. } \\
\text { Quota sampling was } \\
\text { applied. } \\
\text { Reliability (Cronbach's } \\
\text { alpha) was } 0.743 \text {. SPSS } \\
19.0 \text { was used for } \\
\text { descriptive statistics, } \\
\text { factor analysis, k-means } \\
\text { cluster analysis, chi- } \\
\text { squared test, ANOVA, } \\
\text { and multiple regression } \\
\text { analysis. } \\
\text { The diffusion of innova- } \\
\text { tion model was ana- }\end{array}$ & \begin{tabular}{|l|} 
Optimism, \\
Innovativeness, \\
Discomfort, \\
Insecurity, \\
Relative Ad- \\
vantage, Com- \\
patibility, Com- \\
plexity, Observ- \\
ability, Trialabil- \\
ity, Mobile \\
learning self- \\
efficacy, Mobile \\
learning re- \\
sistance, Status \\
quo bias, inten- \\
tion to use (ITU)
\end{tabular} & $\begin{array}{l}\text { Innovation is seen as following the } \\
\text { skills and requisites. } \\
\text { M-learning improves consumers' } \\
\text { reassurance towards innovation. } \\
\text { In contrast, if the latest technology } \\
\text { is irreconcilable with consumers' } \\
\text { lives, they might endure anxiety or } \\
\text { even suffer from technophobia. } \\
\text { Observability towards innovation } \\
\text { has a significant impact on the ITU } \\
\text { towards m-learning. } \\
\text { Individual resistance act as a predic- } \\
\text { tor for adoption and barriers of } \\
\text { innovation diffusion. } \\
\text { The intention to use m-learning is } \\
\text { directly related to the learning costs } \\
\text { involved by using mobile phones. }\end{array}$ \\
\hline
\end{tabular}




\begin{tabular}{|c|c|c|c|c|}
\hline & & lysed. & & \\
\hline \begin{tabular}{|l|} 
Wai et al. \\
$(2018)$ \\
{$[38]$}
\end{tabular} & $\begin{array}{l}\text { Exploring } \\
\text { undergraduate } \\
\text { students' usage } \\
\text { pattern of mo- } \\
\text { bile apps for } \\
\text { education }\end{array}$ & $\begin{array}{l}\text { Data were collected } \\
\text { from } 150 \text { subjects, } 50 \\
\text { each from each faculty } \\
\text { concerned, through an } \\
\text { online questionnaire. } \\
\chi^{2} \text {-test and ANOVA } \\
\text { were used for data } \\
\text { analysis. TAM model } \\
\text { was analysed using } \\
\text { SmartPLS. }\end{array}$ & $\begin{array}{l}\text { Perception of } \\
\text { ease of use, } \\
\text { perception of } \\
\text { usefulness, } \\
\text { Overall attitude } \\
\text { (OA), Actual } \\
\text { Use }\end{array}$ & $\begin{array}{l}\text { Perception of the ease of use, per- } \\
\text { ception of the usefulness, and OA } \\
\text { of students was significant for } \\
\text { actual use. }\end{array}$ \\
\hline $\begin{array}{l}\text { Issara- } \\
\text { manoros } \\
\text { et al. } \\
(2018) \\
{[39]}\end{array}$ & $\begin{array}{l}\text { Auto Mechanic } \\
\text { Students' Per- } \\
\text { ceptions and } \\
\text { Readiness } \\
\text { toward Mobile } \\
\text { Learning in } \\
\text { Thailand }\end{array}$ & $\begin{array}{l}\text { Data were collected } \\
\text { from } 384 \text { auto mechanic } \\
\text { students selected via } \\
\text { multistage sampling. } \\
\text { SPSS was used for the } \\
\text { analysis of data. }\end{array}$ & $\begin{array}{l}\text { PE, EE, SI, FC, } \\
\text { HM, and PI }\end{array}$ & $\begin{array}{l}\text { EE proved to be the most significant } \\
\text { factor towards BI. } \\
\text { PE was an insignificant predictor of } \\
\text { intention to accept m-learning. }\end{array}$ \\
\hline \begin{tabular}{|l|} 
\\
\\
\\
\\
Thongsri \\
et al. \\
$(2018)$ \\
{$[17]$}
\end{tabular} & $\begin{array}{l}\text { Integrating } \\
\text { UTAUT and } \\
\text { UGT to explain } \\
\text { behavioural } \\
\text { intention to use } \\
\text { m-learning: } \\
\text { A developing } \\
\text { country's per- } \\
\text { spective }\end{array}$ & $\begin{array}{l}\text { Data was collected from } \\
359 \text { respondents through } \\
\text { a questionnaire designed } \\
\text { on a five-point Likert } \\
\text { scale. UTAUT and UGT } \\
\text { model were analysed. }\end{array}$ & $\begin{array}{l}\text { Intention to use } \\
\text { m-learning, EE, } \\
\text { PE, SI, Cogni- } \\
\text { tive need, Affec- } \\
\text { tive need, Social } \\
\text { need }\end{array}$ & $\begin{array}{l}\text { Results revealed that PE, cognitive } \\
\text { need, affective need, and social } \\
\text { need significantly affected using m- } \\
\text { learning. Significant effect of } \\
\text { cognitive need on PE and social } \\
\text { need on EE was found. } \\
\text { PE, EE, and SI had a significant } \\
\text { influence on respondents' BI. } \\
\text { Research findings showed that there } \\
\text { is a high correlation between UGT } \\
\text { \& UTAUT. } \\
\text { EE and SI were insignificant on } \\
\text { respondents' BI, while PE was } \\
\text { found to be the most critical factor } \\
\text { for predicting BI. }\end{array}$ \\
\hline $\begin{array}{l}\text { Fadzil } \\
(2018) \\
{[40]}\end{array}$ & \begin{tabular}{|l} 
A Study on \\
Factors Affect- \\
ing the Behav- \\
ioural Intention \\
to Use Mobile \\
Apps in Malay- \\
sia
\end{tabular} & $\begin{array}{l}100 \text { fully completed } \\
\text { questionnaires; through } \\
\text { a self-administered } \\
\text { questionnaire using } \\
\text { email; respondents } \\
\text { selected are experts in } \\
\text { the m-device industry; } \\
\text { analysed using } \\
\text { Statistical Package for } \\
\text { Social Sciences (SPSS); } \\
\text { Pearson correlation is } \\
\text { used to examine the } \\
\text { association between } \\
\text { variables; multiple } \\
\text { regression analyses } \\
\text { (MRA) were conducted } \\
\text { to analyse the direct } \\
\text { relationship }\end{array}$ & $\begin{array}{l}\text { BI, EE, FC, HB, } \\
\mathrm{HM}, \mathrm{PE}, \mathrm{PV}, \mathrm{SI}\end{array}$ & $\begin{array}{l}\text { PV, HB, SI, and HM were found to } \\
\text { be significant with BI. } \\
\text { PE, EE, and FC were not significant } \\
\text { with BI. }\end{array}$ \\
\hline \begin{tabular}{|l|} 
Briz- \\
Ponce et \\
al. (2017) \\
{$[41]$}
\end{tabular} & $\begin{array}{l}\text { Learning with } \\
\text { mobile technol- } \\
\text { ogies students } \\
\text { behaviour }\end{array}$ & \begin{tabular}{|l|} 
Data were collected \\
from 160 students \\
through convenience \\
sampling, and a 5-point \\
Likert scale was used. \\
The software SmartPLS \\
and the SPSS were used
\end{tabular} & \begin{tabular}{|l} 
PU, PEOU, SI, \\
Attitude toward the \\
use of technology, \\
Self-efficacy, \\
Anxiety, BI to use \\
new technology, \\
Reliability \&
\end{tabular} & $\begin{array}{l}\text { PU, PEOU, and SI have a positive } \\
\text { impact on user's Attitudes towards } \\
\text { the use of technology. } \\
\text { User's Attitude has a significant } \\
\text { favourable influence on the degree } \\
\text { of recommendation or the necessity } \\
\text { of a pp certification. }\end{array}$ \\
\hline
\end{tabular}




\begin{tabular}{|c|c|c|c|c|}
\hline & & $\begin{array}{l}\text { to computerize and } \\
\text { analyse the data. TAM } \\
\text { and UTAUT model } \\
\text { were analysed. }\end{array}$ & Recommendation & $\begin{array}{l}\text { Reliability and recommendation } \\
\text { were the most significant drivers of } \\
\text { BI towards using apps for learning. }\end{array}$ \\
\hline Kim et al. & \begin{tabular}{|l|} 
Understanding \\
the role of user \\
resistance on \\
mobile learning \\
usage among \\
university \\
students
\end{tabular} & $\begin{array}{l}\text { Data was collected from } \\
493 \text { students by online } \\
\text { survey. } \\
\text { Innovation diffusion } \\
\text { theory (IDT) and model } \\
\text { of innovation resistance } \\
\text { (MIR) were analysed. }\end{array}$ & $\begin{array}{l}\text { Relative ad- } \\
\text { vantage, Com- } \\
\text { plexity, Inertia, } \\
\text { Innovativeness, } \\
\text { Mobile learning } \\
\text { resistance, } \\
\text { Intention to use } \\
\text { mobile learning }\end{array}$ & $\begin{array}{l}\text { The relative advantage was found to } \\
\text { be a highly prominent predictor of } \\
\text { intention to use m-learning. } \\
\text { Complexity was not significant in } \\
\text { the intention to use m-learning. } \\
\text { Personal innovativeness was dis- } \\
\text { covered to increase the students' } \\
\text { intention to use m-learning. }\end{array}$ \\
\hline \begin{tabular}{|l|} 
\\
Isaias et \\
al. (2017) \\
{$[42]$}
\end{tabular} & \begin{tabular}{|l|} 
Empathic tech- \\
nologies for \\
distance/mobile \\
learning: An \\
empirical re- \\
search based on \\
the unified \\
theory of ac- \\
ceptance and \\
use of technolo- \\
gy (UTAUT)
\end{tabular} & $\begin{array}{l}\text { Data was collected via } \\
\text { an online questionnaire } \\
\text { from } 79 \text { students. } \\
\text { SmartPLS was used for } \\
\text { the analysis of data. The } \\
\text { extended UTAUT } \\
\text { model } \\
\text { was analyzed. }\end{array}$ & $\begin{array}{l}\text { PE, EE, FC, } \\
\text { Social factors, } \\
\text { Attitudes toward } \\
\text { empathic fo- } \\
\text { rums, BI }\end{array}$ & $\begin{array}{l}\text { PE and EE have a significant effect } \\
\text { on the students' attitudes towards } \\
\text { empathic forums. } \\
\text { SI and FC have no significant effect } \\
\text { on the student's attitudes towards } \\
\text { empathic forums. }\end{array}$ \\
\hline $\begin{array}{l}\text { Karimi } \\
(2016) \\
{[43]}\end{array}$ & \begin{tabular}{|l|} 
Do learners' \\
characteristics \\
matter? An \\
exploration of \\
mobile learning \\
adoption in self- \\
directed learning
\end{tabular} & $\begin{array}{l}\text { Data were collected } \\
\text { from } 130 \text { undergraduate } \\
\text { students using a 7-point } \\
\text { Likert scale. Regression } \\
\text { analysis was used for } \\
\text { the analysis of data. }\end{array}$ & $\begin{array}{l}\text { Innovativeness, } \\
\text { learning style } \\
\text { inventory, EE, } \\
\text { PE, Perceived } \\
\text { playfulness; } \\
\text { Intention to } \\
\text { adopt }\end{array}$ & $\begin{array}{l}\text { The learning style of students in m- } \\
\text { learning plays an essential role in its } \\
\text { adoption. } \\
\text { Playfulness and performance expec- } \\
\text { tancy acts as a vital sign of m- } \\
\text { learning adoption. } \\
\text { PE has a considerable impact on the } \\
\text { usage of mobile phones in the } \\
\text { formal education system. } \\
\text { EE was insignificant on m-learning } \\
\text { adoption amongst undergraduate } \\
\text { students. }\end{array}$ \\
\hline $\begin{array}{l}\text { Han \& } \\
\text { Shin } \\
(2016) \\
{[44]}\end{array}$ & \begin{tabular}{|l|} 
The use of a \\
mobile learning \\
management \\
system and \\
academic \\
achievement of \\
online students
\end{tabular} & $\begin{array}{l}\text { Data was collected from } \\
1,604 \text { respondents: five- } \\
\text { point Likert scale } \\
\text { TAM and ISS model is } \\
\text { analysed }\end{array}$ & \begin{tabular}{|l|} 
Self-Efficacy, \\
Innovativeness, \\
Attitude toward \\
technology, PU, \\
PEOU, Subjec- \\
tive Norm, \\
Perceived system \\
accessibility
\end{tabular} & $\begin{array}{l}\text { Self-efficacy, innovativeness, and } \\
\text { perceived ease of use are significant } \\
\text { predictors of the adoption of new } \\
\text { technology. } \\
\text { Personal innovation influenced the } \\
\text { adoption of m-learning. }\end{array}$ \\
\hline \begin{tabular}{|l|} 
Hao et al. \\
$(2016)$ \\
{$[45]$}
\end{tabular} & $\begin{array}{l}\text { Influential } \\
\text { factors for } \\
\text { mobile learning } \\
\text { acceptance } \\
\text { among Chinese } \\
\text { users }\end{array}$ & \begin{tabular}{|l|} 
Data was collected from \\
282 undergraduate \\
students using the \\
snowball sampling \\
method. \\
Exploratory factor \\
analysis \& path analysis \\
was used to test m- \\
learning acceptance \\
model.
\end{tabular} & \begin{tabular}{|l|} 
PU, PEOU, FC, \\
Image, Subjec- \\
tive norm, \\
Voluntariness, \\
PI, BI
\end{tabular} & $\begin{array}{l}\text { Pedagogy acts as a significant } \\
\text { driver to influence the adoption of } \\
\text { m-learning. } \\
\text { SI, social image \& subjective norm } \\
\text { were significant factors that influ- } \\
\text { ence usage of m-learning. } \\
\text { PI did not have a direct effect on m- } \\
\text { learning adoption }\end{array}$ \\
\hline $\begin{array}{l}\text { Althu- } \\
\text { nibat } \\
(2015) \\
{[46]}\end{array}$ & \begin{tabular}{|l|} 
Determining the \\
factors influenc- \\
ing students' \\
intention to use
\end{tabular} & \begin{tabular}{|l|} 
Data was collected from \\
239 students across \\
universities through a \\
questionnaire. Multiple
\end{tabular} & $\begin{array}{l}\text { PU, PEOU, BI, } \\
\text { Self-efficiency, } \\
\text { FC, Services } \\
\text { quality }\end{array}$ & $\begin{array}{l}\text { PU, PEOU, and services quality has } \\
\text { a significant impact on BI of using } \\
\text { m-learning }\end{array}$ \\
\hline
\end{tabular}




\begin{tabular}{|c|c|c|c|c|}
\hline & $\begin{array}{l}\text { m-learning in } \\
\text { Jordan higher } \\
\text { education }\end{array}$ & $\begin{array}{l}\text { regression analysis was } \\
\text { used for analysis. TAM, } \\
\text { TRA \& UTAUT model } \\
\text { were analysed. }\end{array}$ & & \\
\hline $\begin{array}{l}\text { Joo et al. } \\
(2014) \\
{[47]}\end{array}$ & $\begin{array}{l}\text { Factors Influ- } \\
\text { encing Actual } \\
\text { Use of Mobile } \\
\text { Learning Con- } \\
\text { nected with E- } \\
\text { Learning }\end{array}$ & $\begin{array}{l}\text { Data was collected from } \\
238 \text { people using a 5- } \\
\text { point Likert scale. } \\
\text { SEM was used to ana- } \\
\text { lyse structural relation- } \\
\text { ships between relevant } \\
\text { variables and actual use } \\
\text { of m-learning; AMOS } \\
\text { was used as a measure- } \\
\text { ment model. UTAUT } \\
\text { model was analysed. }\end{array}$ & $\begin{array}{l}\text { Self-efficacy, } \\
\text { PE, EE, SI, FC, } \\
\text { Intention of use, } \\
\text { and Actual } \\
\text { Behaviour }\end{array}$ & $\begin{array}{l}\text { PE, EE, SI, and FC did not have a } \\
\text { significant effect on the BI. } \\
\text { Mobile self-efficacy and perfor- } \\
\text { mance expectancy directly impact } \\
\text { intention of use, and intention of } \\
\text { use affects actual behaviour. }\end{array}$ \\
\hline $\begin{array}{l}\text { Viberg \& } \\
\text { Grönlund } \\
(2013) \\
{[48]}\end{array}$ & \begin{tabular}{|l|} 
A cross-cultural \\
analysis of \\
users' attitudes \\
toward the use \\
of mobile devic- \\
es in second and \\
foreign language \\
learning in \\
higher educa- \\
tion: A case \\
from Sweden \\
and China
\end{tabular} & $\begin{array}{l}\text { Online questionnaires \& } \\
\text { paper forms were both } \\
\text { used to collect the data } \\
\text { from } 345 \text { respondents. } \\
\text { Hofstede's cultural } \\
\text { constructs were evaluat- } \\
\text { ed. }\end{array}$ & \begin{tabular}{|l|} 
Power distance; \\
Individualism- \\
collectivism; \\
Uncertainty \\
avoidance; Long \\
vs. short-term \\
orientation; Mascu- \\
linity-femininity; \\
Indulgence vs. \\
restraint; Personali- \\
zation authenticity; \\
collaboration
\end{tabular} & $\begin{array}{l}\text { The findings show respondents' } \\
\text { attitudes toward m-learning are } \\
\text { highly positive, with individualiza- } \\
\text { tion being most optimistic }(83 \%) \\
\text { followed by collaboration }(74 \%) \\
\text { and authenticity }(73 \%) \text {. } \\
\text { The statistical analysis indicates that } \\
\text { Hofstede's factors cannot explain } \\
\text { the differences in mobile-assisted } \\
\text { language learning (MALL) attitudes } \\
\text { in the chosen sample. }\end{array}$ \\
\hline $\begin{array}{l}\text { Jambu- } \\
\text { lingam } \\
(2013) \\
{[49]}\end{array}$ & $\begin{array}{l}\text { Behavioural } \\
\text { Intention to } \\
\text { Adopt Mobile } \\
\text { Technology } \\
\text { among Tertiary } \\
\text { Students }\end{array}$ & \begin{tabular}{|l} 
Data was collected from \\
351 respondents through \\
a questionnaire using a \\
5-point Likert scale. For \\
analysis, confirmative \\
factor analysis (CFA), \\
composite reliability \\
(CR), and Average \\
Extracted Variance \\
(AVE), SEM, and \\
AMOS were used. \\
UTAUT model was \\
analysed.
\end{tabular} & $\begin{array}{l}\text { PE, EE, FC, SI, } \\
\text { Affordability, } \\
\text { Pedagogy }\end{array}$ & $\begin{array}{l}\text { Affordability and Pedagogy have a } \\
\text { significant effect on student adoption of } \\
\text { Mobile technology learning environ- } \\
\text { ments (MTLE). } \\
\text { PE has a significant effect on student } \\
\text { adoption towards MTLE. } \\
\text { EE and SI was an insignificant predictor } \\
\text { of BI. } \\
\text { Affordability is the most significant } \\
\text { predictor of BI that influences MTLE } \\
\text { adoption. } \\
\text { There is no significant effect of modera- } \\
\text { tors' age and gender on MTLE adoption. }\end{array}$ \\
\hline $\begin{array}{l}\text { Abu-Al- } \\
\text { Aish \& } \\
\text { Love } \\
(2013) \\
{[13]}\end{array}$ & $\begin{array}{l}\text { Factors Influ- } \\
\text { encing Students' } \\
\text { Acceptance of } \\
\text { m-learning: An } \\
\text { Investigation in } \\
\text { Higher Educa- } \\
\text { tion }\end{array}$ & $\begin{array}{l}\text { Data was collected from } \\
174 \text { respondents through } \\
\text { questionnaire. Principal } \\
\text { components extraction } \\
\text { with varimax rotation } \\
\text { using SPSS } 16, \text { CFA } \\
\text { using AMOS-16 was } \\
\text { used to analyse it. }\end{array}$ & $\begin{array}{l}\text { PE, EE, Lectur- } \\
\text { ers' influence, } \\
\text { Quality of ser- } \\
\text { vice (QS), PI, BI }\end{array}$ & $\begin{array}{l}\text { PE, EE, lecturers, QS, and PI, were } \\
\text { all significant factors that affect BI } \\
\text { to use m-learning. } \\
\text { QS and personal innovativeness } \\
\text { were added to the structure of } \\
\text { UTAUT \& provide practitioners } \\
\text { and educators with valuable rec- } \\
\text { ommendations for designing an } \\
\text { implied m- learning system. }\end{array}$ \\
\hline
\end{tabular}

\section{Discussion}

The main objective of this research is to identify the factors influencing m-learning in higher education. The thirty-five studies discussed in this paper are a few relevant studies contributed by different authors in identifying factors influencing higher edu- 
cation students towards m-learning. The essential behavioural theories in literature which suggest investigating the user's willingness to accept or adopt new innovative technology are Theory of Reasoned Action (TRA), Theory of Planned behaviour (TPB), Theory of Interpersonal behaviour (TIB). Also, there are the Technology Acceptance Model (TAM), Extended Technology Acceptance Model (ETAM), Social Cognitive Theory (SCT), Diffusion of Innovation Theory (DOI), Uses and Gratification Theory (UGT), Unified Theory of Acceptance Use of Technology (UTAUT), extended UTAUT model and many more.

The initial theories (SCT, TIB, and TRA) were psychosocial theories that have proven their efficacy in predicting and explaining numerous human behaviours in varying situations. Further, the DOI focused on describing individuals' behaviour while TRA and TPB concentrate on adopting an organization's decisions. Another model rooted in the theory of human behaviour is TAM, introduced by Davis (1989). According to this theory, the factors influencing the user to adopt new technology are PU and PEOU. The opinion of an individual depends on age and gender.

Contrary to it, pre-service teachers' research positively responds to mobile devices for learning, irrespective of age and gender [50]. TAM is regarded as the most significant paradigm in literature for assessing the adoption of new technology by users. Conversely, despite frequent use, it has been criticized by various authors on the ground of little explanation, heuristic values, triviality, and lack of practical value [51]. TAM has been widely criticized, despite its frequent use, leading researchers to redefine it.

As per the reference [48] extended the original TAM model as TAM2 to explain perceived usefulness and usage intentions in terms of social influence (subjective norms, voluntariness, image) and cognitive instrumental processes (job relevance, output quality, result demonstrability, perceived ease of use). Further, as per the reference [52], Venkatesh developed the Unified theory of acceptance and use of technology (UTAUT) by integrating all the eight models applied to an individual's usage behaviour. According to the reference [53] Two new dependent variables were introduced, i.e., behavioural intention and usage behaviour, eight independent variables included in the theory are performance expectancy, effort expectancy, social influence, facilitating condition, gender, age, experience, and voluntariness of use. Amongst UTAUT constructs, the researchers discovered that EE and PE influenced SI in m-learning, while on the other hand, FC and intention of use affected users' actual user behaviour. In addition to this, few researchers found that self-efficacy also affects the actual use behaviour [17]. According to the literature, the UTAUT model has been proved as the most precise model for assessing user acceptance towards a technology. The UTAUT is considered the modern model for analysing user BI factors towards any new technology and the actual use.

This paper mainly discussed the DOI, TAM, UTAUT, and extended UTAUT models of user acceptance theory. The papers considered in the present study are mainly of the previous five years; hence, most researchers have discussed UTAUT and extended UTAUT models in their study. 


\section{Conclusion}

In recent years, a rapid increase in mobile phone usage has been witnessed; many users belong to higher education students. M-learning provides them an opportunity to embed learning in both formal and informal education settings [54],[5]. In the current technological environment, parents intend to boost their children towards using $\mathrm{m}$ learning [55]. Studies discussed in the paper demonstrated how mobile could be used as a communication tool to support teaching and learning in today's technologically advanced environment. M-learning promotes collaborative learning, easy sharing of audio and video contents; record-keeping features aid learners to study the contents quickly and easily, when and where required [56]. In addition to it, as per the reference [57], coding accelerates learning and thinking capability in young age children who are apt to a range of technological tools. The significant features of m-learning like flexibility for learning, access to brief materials, multimedia learning, and content review help enhance traditional education methods. Furthermore, as per the reference [58], educational apps attain the requisite content and resources to reinforce active learning and productive learning activities among young children.

\section{Scope for Further Research}

Further studies can focus on one of the biggest challenges associated with $\mathrm{m}$ learning: the availability, or lack thereof, of internet services and its cost-prohibitive nature, especially for people residing in remote areas and with limited financial and other resources along with compromised infrastructure. Future studies can also explore accessible evaluation tools for learning and emphasize their strengths, limitations, and integrity. They can also study instructors' prerequisites for an appropriate, fast, and easy-to-use tool while assessing educational apps. Researchers can think in the direction of reference [59-61], whereby they emphasized the importance of new technology usage in the early childhood education system and its impact on young children's learning. Further to enhance students' knowledge, digital education pedagogy can be designed to build their content and share amongst themselves. This increases students' motivation, and their learning goals can be achieved via fun and enjoyable activities [62],[7],[63]. In support of the study mentioned previously, discussed the pertinent purposes of the educational apps, young students' potentials, and teachers' implied demands for evaluating educational apps for children considering four factors: usability, efficiency, parental control, and security [58]. The role of government, non-governmental organizations (NGO), not-for-profit (NFP) organizations, public-private partnerships (PPP), and institutions (universities, colleges, and schools) in the context of m-learning and e-learning resources can be studied considering K-12 students. 


\section{$7 \quad$ References}

[1] H.-J. Kim and J.-Y. Rha, "Predicting the drivers of the intention to use mobile learning in South Korea,” Int. J. Interact. Mob. Technol., vol. 12, no. 1, p. 116, 2018. https://doi.org/ 10.3991/ijim.v12i1.7688

[2] H.-J. Kim, J.-M. Lee, and J.-Y. Rha, "Understanding the role of user resistance on mobile learning usage among university students," Computers \& Edu., vol. 113, pp. 108-118, 2017. https://doi.org/10.1016/j.compedu.2017.05.015

[3] M. Kuciapski, "Students acceptance of m-learning for higher education - UTAUT model validation," in Information Systems: Development, Research, Applications, Education, Cham: Springer International Publishing, 2016, pp. 155-166. https://doi.org/10.1007/9783-319-46642-2 11

[4] M. Ally, Mohamed. "Using learning theories to design instruction for mobile learning devices." Mobile Learning Anytime Everywhere, pp. 5-8, 2005.

[5] A. Kukulska-Hulme et al., "Mature students using mobile devices in life and learning," Int. J. Mob. Blended Learn., vol. 3, no. 1, pp. 18-52, 2011.

[6] J. B. Venkataraman and S. Ramasamy, "Factors influencing mobile learning: a literature review of selected journal papers,” Int. J. Mob. Learn. Organ., vol. 12, no. 2, pp. 99, 2018.

[7] S. Papadakis, N. Zaranis, and M. Kalogiannakis, "Parental involvement and attitudes towards young Greek children's mobile usage,” Int. J. Child Comput. Interact., vol. 22, p. 100-144, 2019. https://doi.org/10.1016/j.ijcci.2019.100144

[8] K. M. Al-Said, "Students' Perceptions of Edmodo and Mobile Learning and Their Real Barriers towards Them.” Turkish Online J. of Edu. Tech.-TOJET 14, no. 2, 167-180, 2015.

[9] S. A. Nikou and A. A. Economides, "Mobile-based assessment: A literature review of publications in major referred journals from 2009 to 2018," Computers \& Education, Jun2018. https://doi.org/10.1016/j.compedu.2018.06.006

[10] Y.-S. Wang, M.-C. Wu, and H.-Y. Wang, "Investigating the determinants and age and gender differences in the acceptance of mobile learning," Br. J. Educ. Technol., vol. 40, no. 1, pp. 92-118, 2009. https://doi.org/10.1111/j.1467-8535.2007.00809.x

[11] J. C. K. Wang, A. J. S. Morin, R. M. Ryan, and W. C. Liu, "Students' motivational profiles in the physical education context," J. Sport Exerc. Psychol., vol. 38, no. 6, pp. 612-630, 2016. https://doi.org/10.1123/jsep.2016-0153

[12] M. West and S. Vosloo. Directrices de la UNESCO para las políticas de aprendizaje móvil. UNESCO, 2013.

[13] A. Abu-Al-Aish and S. Love, "Factors influencing students' acceptance of m-learning: An investigation in higher education," Int. Rev. Res. Open Distrib. Learn., vol. 14, no. 5, 2013. https://doi.org/10.19173/irrodl.v14i5.1631

[14] Y.-T. Sung, K.-E. Chang, and T.-C. Liu, "The effects of integrating mobile devices with teaching and learning on students' learning performance: A meta-analysis and research synthesis," Comput. Educ., vol. 94, pp. 252-275, 2016. https://doi.org/10.1016/j.compedu. 2015.11 .008

[15] M. El-Masri and A. Tarhini, "Factors affecting the adoption of e-learning systems in Qatar and USA: Extending the Unified Theory of Acceptance and Use of Technology 2 (UTAUT2)," Educ. Technol. Res. Dev., vol. 65, no. 3, pp. 743-763, 2017. https://doi.org/ $\underline{10.1007 / \mathrm{s} 11423-016-9508-8}$

[16] M. El-Masri, K. Al-Yafi, S. Addas, and A. Tarhini, "Individual determinants of IT occupational outcomes," Commun. Assoc. Inf. Syst., vol. 42, pp. 481-507, 2018. https://doi.org/1 $\underline{0.17705 / 1 \text { cais. } 04218}$ 
[17] N. Thongsri, L. Shen, Y. Bao, and I. M. Alharbi, "Integrating UTAUT and UGT to explain behavioural intention to use M-learning: A developing country's perspective,” J. Syst. Inf. Technol., vol. 20, no. 3, pp. 278-297, 2018. https://doi.org/10.1108/jsit-11-2017-0107

[18] D. Moher, A. Liberati, J. Tetzlaff, D. G. Altman, and PRISMA Group, "Preferred reporting items for systematic reviews and meta-analyses: the PRISMA statement," Ann. Intern. Med., vol. 151, no. 4, pp. 264-9, W64, 2009. https://doi.org/10.7326/0003-4819-151-4200908180-00135

[19] X. Zhang et al., "Medical students' attitudes and perceptions towards the effectiveness of mobile learning: A comparative information-need perspective," J. Libr. Inf. Sci., 2020.

[20] F. D. Alotaibi, S. Siraj, and W. M. A. S. Ismail. "Factors Influencing Acceptance to Use M-learning in Learning Arabic Language for Non-native Speakers in Saudi Universities." Opcion, vol. 35, 2019.

[21] S. Hu, K. Laxman, and K. Lee, "Exploring factors affecting academics' adoption of emerging mobile technologies-an extended UTAUT perspective," Educ. Inf. Technol., vol. 25, no. 5, pp. 4615-4635, 2020. https://doi.org/10.1007/s10639-020-10171-x

[22] V. N. Hoi, "Understanding higher education learners' acceptance and use of mobile devices for language learning: A Rasch-based path modelling approach," Comput. Educ., vol. 146, no. 103761, p. 103761, 2020. https://doi.org/10.1016/j.compedu.2019.103761

[23] S. S. Nawaz, H. M. A. Hilmy \& S. Gunapalan, "Islamic Banking Customers' Intention to use Mobile Banking Services: A Sri Lankan Study.” Journal of Advanced Research in Dynamical and Control Systems, vol. 12, pp.1610-1626, 2020.

[24] A. Ameri, R. Khajouei, A. Ameri, and Y. Jahani, "Acceptance of a mobile-based educational application (LabSafety) by pharmacy students: An application of the UTAUT2 model," Educ. Inf. Technol., vol. 25, no. 1, pp. 419-435, 2020. https://doi.org/ $\underline{10.1007 / \mathrm{s} 10639-019-09965-5}$

[25] K. Nikolopoulou, V. Gialamas, and K. Lavidas, "Acceptance of mobile phone by university students for their studies: an investigation applying UTAUT2 model," Educ. Inf. Technol., vol. 25, no. 5, pp. 4139-4155, 2020. https://doi.org/10.1007/s10639-020-10157-9

[26] S. Chatterjee, D. Majumdar, S. Misra, and R. Damaševičius, "Adoption of mobile applications for teaching-learning process in rural girls' schools in India: an empirical study," Educ. Inf. Technol., vol. 25, no. 5, pp. 4057-4076, 2020. https://doi.org/10.1007/s10639$\underline{020-10168-6}$

[27] A. Al-Azawei and A. Alowayr, "Predicting the intention to use and hedonic motivation for mobile learning: A comparative study in two Middle Eastern countries," Technol. Soc., vol. 62, p. 101325, 2020. https://doi.org/10.1016/j.techsoc.2020.101325

[28] M. K. Al-Nawayseh, A. H. Baarah, S. A. Al-Masaeed, and M.-M. M. Alnabhan, "Mobile learning adoption in Jordan: technology influencing fac-tors," International Journal of Networking and Virtual Organisations, no. 4, pp. 400-417, 2019. https://doi.org/10.1504/ invo.2019.10022273

[29] G.-J. Hwang, C.-L. Lai, J.-C. Liang, H.-C. Chu, and C.-C. Tsai, “A long-term experiment to investigate the relationships between high school students' perceptions of mobile learning and peer interaction and higher-order thinking tendencies," Educ. Technol. Res. Dev., vol. 66, no. 1, pp. 75-93, 2018. https://doi.org/10.1007/s11423-017-9540-3

[30] M. Al-Emran, V. Mezhuyev, and A. Kamaludin, "Towards a conceptual model for examining the impact of knowledge management factors on mobile learning acceptance," Technol. Soc., vol. 61, no. 101247, p. 101247, 2020. https://doi.org/10.1016/j.techsoc. $\underline{2020.101247}$ 
[31] C.-M. Chao, "Factors determining the behavioural intention to use mobile learning: An application and extension of the UTAUT model," Front. Psychol., vol. 10, p. 1652, 2019. https://doi.org/10.3389/fpsyg.2019.01652

[32] A. Chavoshi and H. Hamidi, "Social, individual, technological and pedagogical factors influencing mobile learning acceptance in higher education: A case from Iran," Telemat. inform., vol. 38, pp. 133-165, 2019. https://doi.org/10.1016/j.tele.2018.09.007

[33] A. A. Arain, Z. Hussain, W. H. Rizvi, and M. S. Vighio, "Extending UTAUT2 toward acceptance of mobile learning in the context of higher education," Univers. access inf. soc., vol. 18, no. 3, pp. 659-673, 2019. https://doi.org/10.1007/s10209-019-00685-8

[34] M. H. Fagan, "Factors influencing student acceptance of mobile learning in higher education," Comput. Sch., vol. 36, no. 2, pp. 105-121, 2019.

[35] K. Moorthy, T. Tzu Yee, L. Chun T'ing, and V. Vija Kumaran, "Habit and hedonic motivation are the strongest influences in mobile learning behaviours among higher education students in Malaysia," Australas. J. Educ. Technol., vol. 35, no. 4, 2019. https://doi.org/ $10.14742 /$ ajet. 4432

[36] H. Hamidi and M. Jahanshaheefard, "Essential factors for the application of education information system using mobile learning: A case study of students of the university of technology," Telemat. inform., vol. 38, pp. 207-224, 2019. https://doi.org/10.1016/ j.tele.2018.10.002

[37] H. Hamidi and A. Chavoshi, "Analysis of the essential factors for the adoption of mobile learning in higher education: A case study of students of the University of Technology," Telemat. inform., vol. 35, no. 4, pp. 1053-1070, 2018. https://doi.org/10.1016/j.tele. 2017.09.016

[38] I. S. H. Wai, S. S. Y. Ng, D. K. W. Chiu, K. K. W. Ho, and P. Lo, "Exploring undergraduate students' usage pattern of mobile apps for education," J. Libr. Inf. Sci., vol. 50, no. 1, pp. 34-47, 2018.

[39] E. Issaramanoros, J. Khlaisang, and P. Pugsee. "Auto Mechanic Students' Perceptions and Readiness toward Mobile Learning in Thailand." International Journal of Interactive Mobile Technologies, vol. 12, no. 5, 2018. https://doi.org/10.3991/ijim.v12i5.8906

[40] F. Fadzil, "A study on factors affecting the behavioral intention to use mobile apps in Malaysia," SSRN Electron. J., 2017. https://doi.org/10.2139/ssrn.3090753

[41] L. B. Ponce, A. Pereira, L. Carvalho, J. A. Juanes-Méndez, and F. J. G. Peñalvo. "Learning with mobile technologies-Students' behaviour." Computers in Human Behaviour, vol. 72, pp. 612-620, 2017. https://doi.org/10.1016/j.chb.2016.05.027

[42] P. Isaias, F. Reis, C. Coutinho, and J. A. Lencastre, "Empathic technologies for distance/mobile learning: An empirical research based on the unified theory of acceptance and use of technology (UTAUT)," Interact. Technol. Smart Educ., vol. 14, no. 2, pp. 159180, 2017. https://doi.org/10.1108/itse-02-2017-0014

[43] S. Karimi, "Do learners' characteristics matter? An exploration of mobile-learning adoption in self-directed learning," Comput. Human Behav., vol. 63, pp. 769-776, 2016. https://doi.org/10.1016/j.chb.2016.06.014

[44] I. Han and W. S. Shin, "The use of a mobile learning management system and academic achievement of online students," Comput. Educ., vol. 102, pp. 79-89, 2016.

[45] S. Hao, V. P. Dennen, and L. Mei, "Influential factors for mobile learning acceptance among Chinese users," Educ. Technol. Res. Dev., vol. 65, no. 1, pp. 101-123, 2017. https://doi.org/10.1007/s11423-016-9465-2

[46] A. Althunibat, "Determining the factors influencing students' intention to use m-learning in Jordan higher education," Comput. Human Behav., vol. 52, pp. 65-71, 2015. https://doi.org/10.1016/j.chb.2015.05.046 
[47] Y. J. Joo, S. Joung, E. K. Shin, E. Lim, and M. Choi, "Factors influencing actual use of mobile learning connected with E-learning," Computer Science \& Information Technology (CS \& IT), 2014. https://doi.org/10.5121/csit.2014.41116

[48] O. Viberg and Å. Grönlund, "Cross-cultural analysis of users' attitudes toward the use of mobile devices in second and foreign language learning in higher education: A case from Sweden and China," Comput. Educ., vol. 69, pp. 169-180, 2013. https://doi.org/10.1016/j.compedu.2013.07.014

[49] M. Jambulingam, "Behavioural intention to adopt mobile technology among tertiary students." World applied sciences journal, vol. 22, no. 9, pp.1262-1271, 2013.

[50] S. A. Nikou and A. A. Economides, "Mobile-based assessment: Investigating the factors that influence behavioural intention to use," Comput. Educ., vol. 109, pp. 56-73, 2017. https://doi.org/10.1016/j.compedu.2017.02.005

[51] M. Y. Chuttur, "Overview of the technology acceptance model: Origins, developments and future directions." Working Papers on Information Systems, vol. 9, no. 37, pp. 9-37, 2009.

[52] V. Venkatesh and F. D. Davis, "A theoretical extension of the technology acceptance model: Four longitudinal field studies," Manage. Sci., vol. 46, no. 2, pp. 186-204, 2000. https://doi.org/10.1287/mnsc.46.2.186.11926

[53] Venkatesh, Morris, Davis, and Davis, "User acceptance of information technology: Toward a unified view," MIS Q, vol. 27, no. 3, p. 425, 2003. https://doi.org/10.2307/ $\underline{30036540}$

[54] H. Eshach, "Bridging in-school and out-of-school learning: Formal, non-formal, and informal education," J. Sci. Educ. Technol., vol. 16, no. 2, pp. 171-190, 2007. https://doi.org/10.1007/s10956-006-9027-1

[55] S. So, "Mobile instant messaging support for teaching and learning in higher education," Internet High. Educ., vol. 31, pp. 32-42, 2016. https://doi.org/10.1016/j.iheduc.2016. $\underline{06.001}$

[56] J. Sultana, "Determining the factors that affect the uses of Mobile Cloud Learning (MCL) platform Blackboard- a modification of the UTAUT model," Educ. Inf. Technol., vol. 25, no. 1, pp. 223-238, 2020. https://doi.org/10.1007/s10639-019-09969-1

[57] S. Papadakis and M. Kalogiannakis, "A research synthesis of the real value of selfproclaimed mobile educational applications for young children," in Mobile Learning Applications in Early Childhood Education, IGI Global, pp. 1-19, 2020. https://doi.org/10.4018/978-1-7998-1486-3.ch001

[58] S. Papadakis, "Apps to promote Computational Thinking concepts and coding skills in children of preschool and pre-primary school age," in Mobile Learning Applications in Early Childhood Education, IGI Global, pp. 101-121, 2020. https://doi.org/10.4018/978-17998-1486-3.ch006

[59] M. Kalogiannakis, S. Papadakis, and P. Dorouka, "Tablets and apps for promoting robotics, mathematics, STEM education and literacy in early childhood education," Int. j. mob. learn. organ., vol. 14, no. 2, p. 255, 2020. https://doi.org/10.1504/ijmlo.2020.10026334

[60] S. Papadakis, "Evaluating pre-service teachers' acceptance of mobile devices with regards to their age and gender: a case study in Greece," Int. j. mob. learn. organ., vol. 12, no. 4, p. 336, 2018. https://doi.org/10.1504/ijmlo.2018.095130

[61] S. Papadakis, "Tools for evaluating educational apps for young children: a systematic review of the literature," Interact. Technol. Smart Educ., vol. ahead-of-print, no. ahead-ofprint, 2020.

[62] M. Kalogiannakis and S. Papadakis, "Combining mobile technologies in environmental education: a Greek case study,” Int. j. mob. learn. organ., vol. 11, no. 2, p. 108, 2017. 
[63] S. Papadakis, M. Kalogiannakis, V. Orfanakis, and N. Zaranis, "The appropriateness of Scratch and App Inventor as educational environments for teaching introductory programming in primary and secondary education," in Early Childhood Development, IGI Global, pp. 797-819, 2019. https://doi.org/10.4018/978-1-5225-7507-8.ch039

\section{Authors}

Ms. Yuvika Gupta is an Assistant Professor at the School of Management, IMS Unison University, Dehradun, India. She is an academician with over 11 years of teaching experience and MBA and UGC-NET(JRF) qualified. As a focused researcher, she enjoys writing research papers and interacting with fellow researchers at various national and international seminars and conferences. Ms. Yuvika has published over $20+$ peerreviewed research papers in leading management journals indexed in ABDC (Australian Business Deans Council) "B" Category, SCOPUS, Web of Science, and UGC Care. She is also serving as a reviewer in Journals of repute published by Inderscience.

Dr. Farheen Mujeeb Khan is an Assistant Professor at ICFAI Business School (IBS), the ICFAI University, Dehradun, India. Believing that the agricultural sector is the backbone of India's economy, she conducted her doctoral research on "Green Marketing in the Processed Food Industry of India" in 2018. She continues to pursue her post-doctoral fellowship (PDF) research on a Senior Research Fellowship awarded competitively by the prestigious Indian Council of Social Science Research (ICSSR) in 2019. Dr. Khan has to her credit over five research papers published in national and international refereed journals.

Dr Sonal Agarwal is an Associate Professor at the School of Business Management, Datalink Institute of Business and Technology, Tema, Ghana. She has a teaching experience of more than 20 years in India and abroad (Nigeria, Ghana, Benin). She has earned her Doctorate in Commerce from India, entitled "Appraisal of Housing and Urban Development Programme in India" in the Department of Commerce, M.J.P. Rohilkhand University, Bareilly, India in 2004. She holds double Master's degree in Commerce and Economics. She is examiner for renowned institutions like International Baccalaureate and Cambridge International Examination. She has more than 25 research papers published in National and International Journals. She is reviewer for may reputed journals.

Article submitted 2021-03-08. Resubmitted 2021-04-13. Final acceptance 2021-04-13. Final version published as submitted by the authors 